\title{
Performance: travestismos y política en las crónicas de Pedro Lemebel
}

\section{Resumen}

En este trabajo se indagará sobre la relación que existe entre las crónicas urbanas de Pedro Lemebel, La esquina es mi corazón (1995) y Loco afán. Crónicas de sidario (1996), en el contexto de la post-dictadura chilena, y su participación en las performances de Las Yeguas del Apocalipsis, durante la dictadura pinochetista, a las que consideramos una articulación entre cuerpo, política y teatralidad. Este texto parte de las siguientes preguntas: ¿Qué afinidad/es hay entre las crónicas literarias de Lemebel y las performances de Las Yeguas del Apocalipsis? ¿Qué relación existe entre el cuerpo, la homosexualidad, el travestismo y la performance? ¿Cómo se manifiesta ese vínculo en las crónicas de Pedro Lemebel?

Palabras claves

La esquina es mi corazón, Loco afán, Crónicas de sidario, Pedro Lemebel, performance, Las Yeguas del Apocalipsis, cuerpo, homosexualidad, política.

\begin{abstract}
This paper will inquire about the relationship that exists between the urban chronicles of Pedro Lemebel, La esquina es mi corazón (1995) y Loco afán. Crónicas de sidario (1996) -both written during the Chilean post-dictatorship period-, and their participation in the performances by Las Yeguas del Apocalipsis, from the point of view of considering them a link between body, politics and theatricality. The starting points of this text are the following questions: Which is the affinity/ies between Lemebel chronicles and the performances by Las Yeguas del Apocalipsis? What is the relationship between body-homosexuality, transvestism and the performance? How does this relationship appear in the chronicles of Pedro Lemebel?

Keywords

La esquina es mi corazón, Loco afán, Crónicas de sidario, Pedro Lemebel, performances, Las Yeguas del Apocalipsis, body, politics, theatricality.
\end{abstract}




\section{Teatralidad, cuerpo y política}

¿De qué hablamos cuando hablamos de performance? Esta es una pregunta que tendría muchas respuestas según los diferentes enfoques y perspectivas metodológicas y disciplinares. El denominado performance constituye un objeto difícil de clasificar, delimitar o definir. Dentro de las diversas definiciones, la que voy a tomar es la que expone Diana Taylor en la «Introducción» de Estudios avanzados de performance:

Performance [...] implica simultáneamente un proceso, práctica, acto, episteme, evento, modo de transmisión, desempeño, realización y medio de intervención en el mundo. [...]El hecho de que no se pueda definir o contener de manera definitiva es una ventaja para los artistas y teóricos que no pueden realizar sus quehaceres profesionales exclusivamente dentro de las estructuras y disciplinas previstas. (Subrayado mío. 28)

A la cuestión de la indefinición, se agrega la dificultad de especificar el género gramatical de la palabra performance que, lejos de ser un problema, inscribe la posibilidad de ampliar los términos genéricos (masculino y femenino). Es decir, el vocablo adquiere, merced a esa ambigüedad, una potencia singular en lo que respecta a la anulación de fronteras en los géneros artísticos y también habilita un espacio que trasciende el género biológico de los sujetos que la practican. La performance constituye, además, una práctica a la que podemos ubicar en el contexto de las experiencias artísticas contemporáneas herederas de las vanguardias históricas de los años sesenta, y en el marco del conceptualismo. Éste, según Ana Longoni (2007), más que una tendencia o movimiento puntual, constituyó un «giro conceptual» dentro del arte contemporáneo, a partir de los sesenta: 
CATEDRAL TOMADA: Revista literaria latinoamericana / Journal of Latin American Literary Criticism Performance: travestismos y política en las crónicas de Pedro Lemebel

Una vía para entender este giro parte del desplazamiento del objeto artístico en sí hacia la idea, la concepción o el proceso. [...]En un acelerado y generalizado proceso de experimentación, los artistas desbordarán los límites bidimensionales de la pintura para pasar al objeto, y extenderse a producir acciones, happenings y ambientes. La materialidad de la obra también se amplía notablemente, al incorporar no sólo elementos innobles o efímeros (desechos urbanos, restos orgánicos, etc.), sino incluso procedimientos y recursos de otras disciplinas y formas de conocimiento (de la matemática a la sociología). Incluso cualquier aspecto de la realidad se vuelve susceptible de ser señalado y apropiado como "arte". La fragilidad física extrema de las obras, su condición efímera, señalan que el énfasis está puesto más en el proceso que en el resultado final. (1)

Desde esta perspectiva, podemos vincular la performance con el conceptualismo, ya que ella aparece como un modo de desmaterialización del objeto y, a su vez, manifiesta una tensión entre el cuerpo (como soporte de la acción artística) y la obra no como algo acabado sino como un proceso. Pero además de un concepto teórico, la performance puede ser considerada como un lente epistémico y metodológico para observar la cultura y la sociedad desde lo teatral. En este sentido, Taylor plantea que también es un acto de transferencia que permite que la identidad y la memoria colectiva se trasmitan a través de ceremonias compartidas o comportamientos reiterados. Es decir, «performance [...] nos permite analizar eventos como performances. Las conductas de ciudadanía, género, etnicidad e identidad sexual, por ejemplo, son ensayadas y reproducidas a diario en la esfera pública, de manera consciente o inconsciente. » (Taylor 19)

Asimismo, desde este punto de vista, este fenómeno artístico puede ser considerado como un modo o estrategia de acción transformadora, es decir, a 
partir de la manifestación, intervención y ejecución, un sujeto puede transformarse a sí mismo o bien, sus vínculos con otros mediante la utilización de lo teatral y el artificio. Esto se produce porque supone la reiteración de una conducta que se transmite por medio de la letra o escritura, y a través del cuerpo y los gestos. La teatralidad se inscribe en el cuerpo a partir de los ornamentos, vestuarios, maquillajes que se colocan encima y permiten visibilizar a los cuerpos que en otro contexto no hubieran tenido lugar, a la vez que permite establecer un proceso de construcción de esos cuerpos (ligados a la mezcla animal-humano, a la abyección y al travestismo) diferenciándolos del organismo moderno. El artificio y el travestismo se vuelven esenciales en las performances. Estos elementos y definiciones que atañen a la performance serán propiedades fundamentales del colectivo de arte formado por Pedro Lemebel y Francisco Casas en plena dictadura chilena: Las Yeguas del Apocalipsis.

\section{Las Yeguas del Apocalipsis en la cultura postdictatorial chilena.}

A finales de los setenta y principios de los ochenta del siglo xx, un grupo de artistas desarticuló, en plena dictadura chilena, las rutinas de la vida cotidiana a través de «acciones de arte». Específicamente en 1979, tras la violenta interrupción del exilio y la crisis de la militancia, una serie de trabajos escritos, visuales y performáticos se consolidan para reflexionar y poner en cuestión las normas de representación y de la relación entre arte, vida y política en Chile. En ese mismo año surge en ese país el Colectivo de Arte (cada), integrado por Raúl Zurita, Diamela Eltit, Fernando Balcells, Lotty Rosenfeld y Juan Castillo. Las «acciones artísticas» que plantearon estaban vinculadas desde dos perspectivas que se imbricaban: por un lado, producían espectáculos en las calles, convirtiendo a los transeúntes en espectadores y partícipes; por otro, estas acciones implicaban un acto político en plena dictadura. Al respecto, Robert Neustadt (2003) escribe 
CATEDRAL Tomada: Revista literaria latinoamericana / Journal of Latin American Literary Criticism

Performance: travestismos y política en las crónicas de Pedro Lemebel

La noción de la "acción" evocada por el CADA fue de corregir la realidad, tanto la realidad del arte contestatario como la situación política de la dictadura. [...] Del happening heredaron la práctica de usar la ciudad como soporte artístico abierto en la realización (efímera) de una obra colectiva. Pero, en contraste con el happening, el CADA intentó canalizar la energía de la calle de una manera productiva a fin de estimular cambios que si no serían específicos, sí serían definitivamente democráticos. El arte de las acciones de arte del CADA se basaba en nociones democráticas de la estética, que no pretendía imponer ni lecturas ni soluciones fijas. El elemento común de los dos términos -acción y arte- es su acto de realización. La meta, tanto política como estética de las acciones de arte del CADA, era crear acción al hacer arte en el espacio urbano de Santiago de Chile. (1)

El grupo artístico planteó desde sus comienzos una interacción entre arte, política y sociedad y, bajo el alero de la «Escena de Avanzada», se conformó como anti-institucional y antidictatorial. Lo novedoso de la Avanzada (y del grupo cada) es que irrumpe en el contexto de la dictadura chilena cuando las referencias sociales y culturales se habían quebrado, es decir, surge para desgarrar el orden impuesto por la censura y preguntarse por los límites de la práctica artística en una sociedad represiva. En este sentido, era necesario reconstruir los significados, pero no a partir de una representación totalitaria, sino a partir de fragmentos. Como escribe Nelly Richard, teórica chilena que acuñó el término «Escena de Avanzada» para agrupar las acciones artísticas de los grupos que reconceptualizaron el arte en la dictadura, el trabajo que llevaron a cabo versó sobre el desmontaje retórico-discursivo de las ideologías culturales del poder a partir de técnicas posmodernistas, como el recorte, el montaje y el collage. « [Pero] sin nunca dejar de lado la intención de repolitizar el arte, es decir, de afilar el corte insurgente de formas y conceptos que buscaban socavar las representaciones sociales y culturales del discurso autoritario» (Fracturas 21). Y, 
además, la «Avanzada» pretendió que la obra de arte dejara de ser afín a las estructuras de producción artísticas dominantes negando su incorporación al circuito mercantil propio de los Museos o galerías.

Para desestructurar los campos delimitados por las instituciones tradicionales de gestión cultural, estas prácticas artísticas mezclaron géneros, ampliaron la frontera de los soportes técnicos del arte para basarse en lo procesual del cuerpo y recurrieron a conceptos-metáforas para evitar ser censurados por la dictadura,

La necesidad no sólo de mezclar técnicas y género sino de extender el formato circunscripto del arte hasta borrar, incluso, toda frontera de delimitación entre lo artístico y lo no artístico para culminar en la fusión utópica arte / vida (al estilo del grupo CADA) expresaba, primero, una rebeldía contra el sistema de restricciones y prohibiciones con que el autoritarismo militar acataba y vigilaba la circulación de los signos. El gesto de la Avanzada de desobedecer las asignaciones de formato convencionales que fija la tradición artística y literaria denunciaba figuradamente los abusos de autoridad con los que el régimen militar custodiaba las fronteras del Orden. (Richard, Fracturas 16)

El cuerpo del artista y la ciudad constituyeron las armazones artísticas sobre las cuales se apoyaron las experiencias de arte. Algunas de la intervenciones urbanas más importantes fueron: Para no morir de hambre en el arte (1979), Ay Sudamérica (1981), ambas del grupo cada, Una milla de cruces sobre el pavimento (1979), de Lotty Rosenfeld, entre otras. En estas performances lo que se proponía era que a partir de una intervención urbana (que podía ser una mezcla de videos, fotos, instalaciones, mensajes inconclusos) cada uno de los transeúntes devenidos en espectadores y participantes resignificaran cada una de esas intervenciones producidas en los espacios abiertos de la ciudad. Los lugares donde se llevaban a cabo se oponían a los recintos cerrados del arte, como museos 
CATEDRAL TOMADA: Revista literaria latinoamericana / Journal of Latin American Literary Criticism Performance: travestismos y política en las crónicas de Pedro Lemebel

o galerías. También «el cuerpo, en el arte de la performance, actuó como un eje transemiótico de energías pulsionales que, en tiempos de censura, liberaba márgenes de subjetivación rebelde» (Richard, Fracturas 13).

Dentro de este contexto espacio-cultural emerge el colectivo de arte homosexual Las Yeguas del Apocalipsis, formado por Francisco Casas y Pedro Lemebel, quienes intervinieron desde 1987 en el escenario chileno con diversas performances que se inscribían en el cuerpo, un cuerpo travestido, ya que ambos irrumpían vestidos de mujeres: Pedrita y Panchita. Sus acciones de protesta estuvieron orientadas, en un primer momento, a denunciar el régimen de la disciplina que el gobierno militar imponía sobre los cuerpos, y más tarde, en la democracia neoliberal de la pos-dictadura, la crítica se orientó sobre el mercado que convierte todo, especialmente la diferencia, en mercancía y en espectáculo. Sin dudas, el colectivo artístico constituye hoy un referente sustancial dentro del campo de la performance latinoamericana.

Una de las primeras intervenciones de este colectivo artístico fue a fines de 1988 en la Feria del Libro de Santiago (Chile), en el Parque Forestal, y consistió en la presentación del libro A media asta, de Carmen Berenguer. En esta performance inaugural, Pedro y Pancho iban vestidos con los colores de la bandera chilena, ambos caminaban descalzos y tomados de la mano. Sobre el cuerpo llevaban un velo negro en señal de luto. No existen muchos registros de esta intervención, marca del carácter efímero y procesual que poseen las performances. La segunda aparición del dúo fue en el mismo año, 1988, en el Campus de la Facultad de Artes Universales de Chile, y se denominó Refundación de la Universidad de Chile. Invitados por los alumnos, entraron desnudos al recinto, montados a una yegua, parodiando la fundación de Santiago de Chile por Pedro de Valdivia. En este caso, la performance consistió en resignificar la fundación patriótica desde el lugar de la homosexualidad y el cuerpo desnudo.

Se nos ocurrió ir a caballo, como Pedro de Valdivia, y desnudas, como lady Godiva. Nos conseguimos una yegua en Peñalolén. La bajamos en 
Macul con Las Encinas. Allí nos sacamos la ropa, y nos subimos al animal. Se veía muy bonito, como una escultura en movimiento. Más que morbosa, era una imagen tremendamente erótica, con una gran carga de homosexualidad. Vamos pasando frente a un colegio y justo coincide con la salida de los alumnos. Los cabros se quedaron plop viendo el espectáculo. (Casas S/D)

El 12 de octubre de 1989 irrumpieron en los Salones de la comisión de Derechos humanos para pedir justicia por los crímenes impunes a homosexuales. La acción artística se denominó La conquista de América. Bailaron una cueca sobre una alfombra de vidrios rotos de botellas de Coca-cola, que cubría un mapa del continente americano que estaba en el piso. La idea era mostrar, a partir de la sangre de los pies, la cartografía de las muertes ocurridas en el régimen militar, y, al mismo tiempo, denunciar la imposición de la pasión por el consumismo, dirigida desde la dictadura de Pinochet. Luego, en el mismo año, en el Instituto Chile-Francés de la Cultura, Las Yeguas expusieron la muestra fotográfica de Mario Vivados, titulada Lo que el Sida se llevó. En las fotografías, Lemebel y Casas aparecían vestidos con trajes que recordaban el estilo de las divas hollywoodenses. El Instituto donde se llevó a cabo la performance se transformó en un prostíbulo:

que destacaba en vivo a un Pedro-San Sebastián, cuyo martirio eran jeringas que enferman. En San Camilo, tráfico de deseo, pasó lo inverso. Llevaron al jet cultural, hicieron de la calle un set cinematográfico y pintaron estrellas fosforescentes en el asfalto. Ellos también fosforescían con un cuerpo blanco, protegido con una armadura de lápiz. Dibujaron una estrella por cada travesti. Era la noche del cumpleaños de Pinochet. Cuando la acción estaba terminando, el FPMR produjo un apagón. En Santiago oscuro solo brillaban las estrellas de San Camilo. (Robino 2) 
CATEDRAL TOMADA: Revista literaria latinoamericana / Journal of Latin American Literary Criticism

Performance: travestismos y política en las crónicas de Pedro Lemebel

La acción artística urbana mencionada anteriormente por Robino se llamó Estrellada y concluye el ciclo de intervenciones en el Instituto Chile-Francés de Cultura, que estaba emplazado en la calle San Camilo, lugar en el que se realizaba el comercio sexual travesti.

En estas performances públicas, se pueden vislumbrar los elementos con los que Nelly Richard caracterizó a la «Escena de Avanzada» en el contexto de la dictadura chilena: el soporte artístico es el cuerpo, en este caso, el cuerpo travestido, la mezcla de géneros (pintura sobre el cuerpo, literatura, fotografía, instalaciones) y la repolitización del arte apoyada en la denuncia social contra la exclusión (y muerte) de las minorías sexuales. Y, a su vez, este colectivo artístico puede ser pensado desde la concepción de performance como una manera estrategia de acción transformadora, es decir, a partir de la manifestación, intervención y puesto en acto, Lemebel y Casas se transforman a sí mismos $-\mathrm{y}$ sus vínculos con otros- mediante la utilización de lo teatral y el artificio. La teatralidad tatuada en los cuerpos a partir de los ornamentos, vestuarios, maquillajes que se colocan encima permitió poner en escena los cuerpos homosexuales que en ese contexto eran silenciados y violentados.

La coyuntura de la pos-dictadura no es una época que aparece posterior al momento de la dictadura de Pinochet estableciendo un corte ideológico, cultural y económico con respecto a ella ni el retorno a la democracia implica un período de transición como lo designa la teoría social-científica de Brunner. Por el contrario, y como sostiene, Avelar (1999), la transición epocal se dio en la misma dictadura, y el regreso a la democracia significó «la legitimación jurídico-electoral de la exitosa transición llevada a cabo por los militares, es decir, la ecuación última entre libertad política para el pueblo y libertad económica para el capital» (49). Desde la perspectiva del teórico brasileño, el concepto de «pos-dictadura», leída en clave barroca, logra descentralizar los términos con los que la sociología chilena pretendía estudiar y explicar ese período histórico. Si hubo transición fue del Estado al Mercado, pero ésta se dio en la misma dictadura, y en definitiva, «el retorno a la democracia fue estrechamente controlado y en última instancia 
hegemonizado por los mismos regímenes militares» (Avelar 50). De modo que, no existiría un quiebre tajante entre ambos momentos históricos (dictadura y democracia) sino una continuidad. Este continuum se vislumbra también desde las performances de Las Yeguas del Apocalipsis, montadas durante la dictadura y las posteriores producciones artísticas y crónicas literarias de Pedro Lemebel, durante la pos-dictadura, a partir de la intervención política y ética del cuerpo travestido y la homosexualidad.

En la democracia neoliberal, cuando la censura parecía haber sido destituida, las acciones de Las Yeguas del Apocalipsis dejan en claro que las minorías sexuales habían sido incluidas dentro de la sociedad pero para convertirse en espectáculo del mercado. La performance denominada De la Nostalgia, realizada los primeros días del retorno a la democracia (1991) en el teatro Normandie de Santiago, constituyó una parodia de la noche de entrega de los premios Oscar, en la que Pedro Lemebel y Francisco Casas, travestidos, manifestaron la indiferencia que el neoliberalismo tenía sobre el arte local. En este acto se mostró un video de despedida en homenaje al teatro, lugar de encuentro de intelectuales durante el gobierno de Pinochet y convertido en un shopping center durante la democracia. A su vez, la crítica estaba dirigida hacia la copia que Chile hacía del espectáculo hollywoodense en detrimento de la producción artística local.

\section{Crónicas como performance}

Pedro Mardones Lemebel decidió no solo travestirse y convertirse en Pedrita en Las Yeguas del Apocalipsis, sino que, como escritor, al tiempo que dejó de lado su apellido paterno y comenzó a usar al materno, cambió de género textual: pasó del cuento a la crónica. Como afirma el propio Lemebel en una entrevista realizada por Juan Gelpí y Fernando Blanco: 
CATEDRAL TomAdA: Revista literaria latinoamericana / Journal of Latin American Literary Criticism Performance: travestismos y política en las crónicas de Pedro Lemebel

El Lemebel fue un gesto de alianza con lo femenino, inscribir un apellido materno, reconocer a mi madre huacha desde la ilegalidad homosexual y travesti. El resto vino con las Yeguas del Apocalipsis, una experiencia político-cultural que realizamos con Francisco Casas en el Chile custodiado de los ochentas. Quizás esa primera experimentación con la plástica, la acción de arte, la performance, el video o las instalaciones fue decisiva en la mudanza del cuento a la crónica. Es posible que esa exposición corporal en un marco político fuera evaporando la receta genérica del cuento. Más bien se fue permeando con la noticia del diario, con el manifiesto homosexual y acontecer político publiqué en esa época, con ciertas lecturas de mujeres escritoras que entonces daban la pelea. Tal vez, el intemporal cuento se hizo urgencia crónica en los artículos sobre homosexualidad y acontecer político que comencé a publicar en diarios y revistas. No sé, todo eso, las yeguas, el desacato, la invitación a mezclar géneros y artes desnutridas con panfletos militantes, la tentación de iluminar el suceso crudo y apagarle la luz a la verdad ontológica... (Subrayado mío, Blanco, Gelpí 2)

El cronista se conformó a sí mismo a partir de la alianza femenina que estableció desde su corporalidad travestida en las performances del colectivo de Las Yeguas, las cuales, como mencioné anteriormente en relación con la ambigüedad genérica en el nombre performance, conforman también una acción que podríamos pensar como de travestimos. «En Lemebel, la crónica es también el espacio en que las fantasías mortuorias, románticas y sexuales funcionan como narración performática a través de las cuales el sujeto se configura en la simultaneidad del discurrir discursivo» (Sabo, La crónica 5$)^{1}$. Desde este punto

\footnotetext{
${ }^{1}$ En el artículo «La crónica como género en construcción y la construcción del gender. Abordaje desde la performance», María José Sabo propone una hipótesis de lectura para Loco Afán ([1996] 2000) de Pedro Lemebel en función de considerar la crónica como el espacio de auto-construcción
} 
de vista, una pregunta que intentaremos responder y que será el eje vertebrador del artículo es ¿podríamos considerar las crónicas literarias de Pedro Lemebel como un acto de performance desde varios sentidos: el intersticio de géneros, una intervención de denuncia y protesta, la teatralidad como herramienta para hacer ver el cuerpo homosexual desde el margen y una escritura basada en una textualidad corporal?

La crónica como forma genérica subsiste en contacto con otros géneros y/o discursos como el testimonio, el nuevo periodismo, la novela de no-ficción, con los que comparte un modo de narrar con un «notorio impulso hacia el realismo. Son narrativas urgidas por relatar y transferir algo de lo real» (Bernabé 8). Asimismo, conforma un campo en el que se establece una manera particular de enlazar lo real y la narración, y al mismo tiempo es un espacio en el que se permite impugnar «las categorías estéticas que alimentan jerarquías literarias basadas en la distinción entre lo auténtico y la copia, entre la alta cultura y cultura popular, entre los medios masivos y las formas consideradas prestigiosas» (Bernabé 9). A su vez, Juan Poblete, en el artículo «Crónica y Ciudadanía en tiempos de globalización neoliberal: la escritura callejera», considera que la crónica literaria actual

aparece casi indisolublemente ligada a la crisis y transformación neoliberal de las economías y las sociedades latinoamericanas (71) [...] y podría postularse como el género que mediatiza el choque entre las subjetividades heterogéneas de lo social popular y la identificación neoliberal de democracia electoral y económica de mercado como el horizonte único de

performática de una subjetividad disidente a la norma del gender (género) heterónomo. «La propia crónica se pone también "en escena" interpelando otro sistema, el de los géneros literarios, y gestionando su propia posición en él como escritura en devenir, escritura travesti, escritura en construcción.» (5) Si bien acordamos con estos postulados, no adherimos a su idea de la crónica como género menor que repite y cita irreverentemente los géneros que se consideran más legítimo. Por el contrario, sostenemos que la crónica se construye y subsiste en los diferentes campos intelectuales latinoamericanos por el contacto con otros géneros (como la novela, el testimonio, el cuento) y el modo de narrar que expone esta forma trae al presente todo su pasado arcaico que comienza con las Crónicas de Indias y alcana su máxima expresión en el Modernismo. 
CATEdRal Tomada: Revista literaria latinoamericana / Journal of Latin American Literary Criticism

Performance: travestismos y política en las crónicas de Pedro Lemebel

la vida en el momento de su globalización [...] la crónica responde a lo que podría llamarse ciudadanías de emergencia (crisis y aparición) aquellas colocadas en el espacio en que la re y desestructuración de lo nacional por lo trasnacional y global se enfrenta a la presencia física en las ciudades globales de los cuerpos marcados de aquellos que excluye de sus formas segmentadas de inclusión. (85)

Además del contexto económico, político y social (identificación neoliberal de democracia electoral y económica de mercado) que pone en escena la emergencia de las crónicas urbanas de Lemebel, no debemos olvidar las prácticas artísticas operadas sobre el cuerpo trasvestido, el espacio urbano, las denuncias contra la exclusión violenta del Estado y del mercado que llevaron a cabo Las Yeguas del Apocalipsis, mencionadas en el parágrafo anterior. La performance, ahora, se convierte en literatura y la visibilidad de los cuerpos-otros se incorporan y dejan ver en la textualidad de las crónicas de Lemebel. Así, como sostiene Gareca, « la opción de la crónica en detrimento de la novela o el cuento [...] obedece más a una decisión ética que estética, en tanto considera a la literatura escrita a partir de esa época -salvo contadas excepciones- un discurso muy poco comprometido con la realidad más inmediata: la post-dictadura y la emergencia del neo-liberalismo» (1).

\section{La esquina es mi corazón}

La esquina es mi corazón (1995) es el primer libro de crónicas de Pedro Lemebel publicado en la pos-dictadura chilena en una democracia signada por la lógica del neoliberalismo. Este aspecto atraviesa todas las crónicas como a la ciudad misma. El cronista recorre las calles de un Santiago marginal bajo la pulsión del deseo de la figura de la Loca. A su paso va diagramando y 
constituyendo un espacio que el propio Lemebel denomina «la ciudad-anal» que se opone a la norma de «la ciudad real». En este mismo sentido, una cita introductoria que pertenece a una frase de Néstor Perlongher $^{2}$ preludia el deambular del cronista y su alter ego: la Loca. La referencia textual expone que el cuerpo solo conoce a partir del andar, del desplazamiento. Así en, por ejemplo, la crónica llamada «Anacondas en el parque» aparece no solo el espacio público de la ciudad resignificado desde la homosexualidad, sino la comparación del cuerpo con animales: «"El amancebamiento de culebreas que se frotan en el pasto”; “Obreros, empleados, escolares o seminaristas, se transforman en ofidios que abandonan la piel seca de los uniformes, para tribalizar el deseo de un devenir opaco de cascabeles"» (La esquina 4). El parque deja de ser un lugar «normal» para convertirse en una cartografía gobernada por el deseo homo-erótico.

La loca es la figura principal de las crónicas de Lemebel y constituye el hilo que une al escritor con el performance, entendido como aquel que realiza el acto performativo. ${ }^{3}$ Asimismo, en esta figura se retoma la noción de «"género” como una categoría político ideológica no homologable al sexo. En este sentido el género "no es una actuación que un sujeto elija, sino que es performativo puesto que constituye como un efecto al sujeto que parece expresarlo" (Butler 2000: 102). La loca, según Lemebel, no es real; es una metáfora sobre la homosexualidad y la feminidad.» (Urtasun 204). Severo Sarduy, en el libro La simulación (1982), en el que reflexiona principalmente sobre la pintura, plantea desde el comienzo que una de las pulsiones que llevan hacia la disciplina artística tiene su centro en la figura del travesti. «El travesti no imita a

\footnotetext{
2 "Errar es un sumergimiento en los /olores y los sabores, en las sensaciones/de la ciudad. El cuerpo que yerra /‘conoce’ en/con su desplazamiento.” Néstor Perlongher. (Lemebel 2)

${ }^{3}$ Sería interesante revisar la tradición americana del concepto de «loca» que Daniel Link propone en "Cuerpo y memoria en América Latina: El archivo de "la loca" como sujeto colonial» a la luz de la construcción de esta figura en Lemebel. El escritor argentino estudia el archivo desde la perspectiva de la performance para pensar el cuerpo como el lugar donde se guarda la memoria. Link investiga y pone en escena los «archivos coloniales, los documentos de las nacientes repúblicas novomundanas, los textos fundacionales de la América Latina y los partes de prensa que nos llegan desde el fondo de los tiempos, para decirnos que hay vida en el archivo y que la memoria de esas formas de vida se sustrae a los dispositivos de disciplinamiento en el momento mismo en que éstos pretenden administrar la sexualidad americana» (265).
} 
CATEDRAL TOMADA: Revista literaria latinoamericana / Journal of Latin American Literary Criticism

Performance: travestismos y política en las crónicas de Pedro Lemebel

la mujer [...] El travesti no copia; simula, pues no hay norma que invite y magnetice la transformación (13). Y más adelante, comparando al cuerpo travestido con la mariposa en su deseo de transformación que excede todo fin en sí mismo (hipertélicos) escribe: «El travesti, que llega a transformarlo [al cuerpo], y la mariposa, pueden pintarse a sí mismos, hacer de su cuerpo el soporte de la obra, convertir la emanación del color, los aturdidores arabescos y los tintes incandescentes en un ornamento físico, en una "autoplástica"» (15). El travesti simula, se transforma a fuerza de los ornamentos, el maquillaje y los vestuarios que se coloca sobre su cuerpo. Éste constituye su mejor tela para pintar. Y esos elementos le confieren al cuerpo un lugar sobre el que teatralizar la mezcla, la indefinición, el más allá de los géneros. Como con la performance, el cuerpo de la Loca en Lemebel ${ }^{4}$ se convierte en acción, en pintura, en teatro que interviene en la sociedad para postular dos grandes denuncias: en la época de la dictadura, la marginalidad y la represión sobre el cuerpo homosexual, en la democracia, su inclusión como objeto del espectáculo en el mercado neoliberal.

En «El resplandor emplumado del circo Travesti», el cronista-loca narra cómo en el cuerpo travestido se tatúa no sólo la pobreza (producto de políticas económicas que marginan), sino la denuncia a los medios masivos de comunicación en relación con su inclusión como objeto mercantil de la diferencia:

Así el circo Timoteo sigue circulando en casi todas las poblaciones de la periferia, como una corriente de aire vital que se ríe libremente de la moral castiza. Un escenario de travestismo que se parece a cualquier otro, pero sin embargo, por estar confrontado a la penumbra del excedente social, se transforma en radiografía que vislumbra el trasluz de una risa triste. Mueca quebrada por el áspero roce que decora sus bordes. Un flujo que fuga lo precario en una cascada de oropeles baratos, donde las pasiones y

\footnotetext{
${ }^{4}$ La loca y el travesti si bien no son sinónimos en la narrativa lemebeliana conforman «dos variantes donde lo que define a la homosexualidad son formas materiales o imaginarias de devenir mujer». (Zeiger 1)
} 
pequeños deseos del colectivo se evacuan en la terapia farsante del arte vida, del taco plateado en el barro, del encaje roto, la pluma de plumero y los parches de la carpa donde se meterá el viento y la lluvia del invierno. Glamour entumecido que compite con el relámpago de la televisión y le gana, porque los vecinos entre engaño fluorescente y mentira conocida, eligen la dura tabla de la galera para jugar al insulto, que es revertido con la agilidad teatrera de la daga punzante. Así transforman la desventaja transexual en metales de aplausos, que los hacen volver una y otra vez al escenario para mariconear otro poco. (Lemebel 27)

El relámpago de la televisión incorpora a las travestis y los transexuales para convertirlos en mera mercancía pero, al mismo tiempo, esto no se traduce en un sustento económico o mejores condiciones de vida. La desventaja transexual es una desventaja económica, política y social.

Por otro lado, la teoría propuesta por Judith Butler, filósofa estadounidense contemporánea, quien considera que el sexo -al igual que el género - son construcciones sociales y culturales que obran a partir de la performatividad, entendida como una práctica basada en la repetición y en la referencia a través de la cual el discurso hace efectivo lo que nombra, nos otorga herramientas teóricas para reflexionar sobre la figura de la Loca. En el capítulo «Acerca del término queer», en Los cuerpos que importan (2002), Butler realiza un análisis histórico del término queer, el cual pasó de ser un concepto utilizado para estigmatizar a las minorías sexuales (gays y lesbianas) a ser una noción reapropiada por la misma minoría para oponerse a la «normalidad» propuesta desde la lógica heterosexual. La teoría queer es operativa para entender el lugar de la Loca en Lemebel, ya que, según nuestra lectura, cumple una función subversiva en la medida en que refleja las personificaciones mundanas mediante las cuales se establecen y naturalizan los géneros ideales desde el punto de vista heterosexual y que socava el poder de tales géneros al producir esa exposición. A 
CATEDRAL TOMADA: Revista literaria latinoamericana / Journal of Latin American Literary Criticism

Performance: travestismos y política en las crónicas de Pedro Lemebel

su vez, es importante señalar la operación de reapropiación del significado queer a partir del método de la cita:

[...] el sujeto encasillado como "queer" en el discurso público a través de interpelaciones homofóbicas de diverso tipo retoma o cita ese mismo término como base discursiva para ejercer la oposición. Esta clase de cita se manifestará como algo teatral en la medida que imite y haga hiperbólica la convención discursiva que también invierte. (Butler 326)

Esto se puede analizar en las crónicas de Lemebel a partir de la figura que emerge reiteradamente en la voz del cronista y a la que coloca como testigo y protagonista de las denuncias hacia el Estado que la considera anormal. En este aspecto, la crónica se vuelve performance, en el sentido de ser una acción del arte en que se utiliza como soporte al cuerpo devenido otro para desde allí denunciar:

El cuerpo como simulacro cosmético y parodia que se burla del binarismo sexual de las identificaciones de género permitió que una gestualidad no codificada por el discurso público hiciera aflorar ciertos estratos de significación reprimida que accedieron así, performativamente, a una fluyente superficie de enunciación. (Richard 19)

Por otro lado, la cartografía que este primer libro diagrama está encuadrada en la esquina que constituye no solo un lugar donde habitan algunos de los jóvenes excluidos de la planificación urbana, quienes a su vez están expuestos a la criminalidad, la delincuencia y la violencia (aparece en «La esquina es mi corazón o los New Kids del bloque»), sino del pasear de la Loca. De este modo y como afirma Marta Sierra en un ensayo titulado «Los espacios de la crónica en La esquina es mi corazón», «Lemebel acude a "la esquina" como el 
cronotopo desde el cual el cronista establece una política de la diferencia que represente a los márgenes sociales de la post- dictadura chilena» (90).

El cuerpo de la Loca (sus deseos, aspiraciones, pasiones, su marginalidad) es el cuerpo diferente que emerge en las crónicas como tema y también como acto de intervención de denuncia tanto de la marginalidad (porque a pesar de que retornó la democracia, siguen siendo excluidos y asesinados) como de la inclusión a partir del mercado, como un valor de cambio. Y por esto, las crónicas parten del fragmento, del detalle, para contraponerse a los grandes relatos que ofrece el neoliberalismo. Desde el margen, la figura que crea Lemebel es el fragmento que el cronista decide invocar, desde su propia voz, para develar lo nefasto de la sociedad chilena. Detrás de las fiestas, del deseo, las crónicas revelan la otra cara de la libertad de expresión de la democracia. Por ejemplo, en «Las amapolas también tienen espinas», el cronista retrata el desenlace trágico de un travesti tras perseguir su «deseo de turno»:

La loca sabe el fin de estas aventuras, presiente que el después deviene fatal, sobre todo esta noche cargada de reviente [...] Pareciera que el homosexual asume cierta valentía en esta capacidad infinita de riesgo, rincodeando la sobre en su serpentina de echar el guante al primer macho que le corresponda el guiño. Algo así como desafiar los roles y contaminar las fronteras. (subrayado mío, Lemebel 31)

Tal vez por el deseo de contaminar las fronteras, encuentra la muerte que es narrada a partir de los excesos de metáforas, comparaciones, vocabulario propio de una escritura barroca que imprime pliegues al lenguaje, como escamoteando el significado de la muerte. Una textualidad que se asemeja al cuerpo trasvestido de la Loca en función de los ornamentos y artificios que coloca sobre el lenguaje comunicativo: 
CATEDRAL TomAdA: Revista literaria latinoamericana / Journal of Latin American Literary Criticism

Performance: travestismos y política en las crónicas de Pedro Lemebel

Como si el estoque fuera una picana eléctrica y sus descargas cobraran la carne tersa, estirándola, mostrando nuevos lugares vírgenes para otra cuchillada. Sitios no vistos en la secuencia de poses y estertores de la loca teatrera en su agonía [...] Calada en el riñón la marica en pie hace de aguante, posando Monroe al flashazo de los cortes, quebrándose Marilyn a la navaja Polaroid que abre la gamuza del lomo modelado a tajos por la moda del destripe [...] La marica maniquí luciendo el look siempre viva en la pasarela del charco, burlesca en el muac de besos que troca por una destellada, irónica en el gesto cinematográfico ofrece sus labios machucados al puño que los clausura. (Lemebel 32)

En el final de la crónica, luego de la proliferación de imágenes que acopla la muerte con el cine, la moda y la violencia, Lemebel expone sentencioso que la violencia contra los homosexuales excede la simple pelea, venganza o robo, son, en cambio, «carnicerías del resentimiento social que se cobran en el pellejo más débil, el más expuesto. El corazón gitano de las locas que buscan una gota de placer en las espinas de un rosal prohibido» (Lemebel 32).

En «Tarántulas en el pelo», la Loca deviene peluquera, que trabaja en la simulación cosmética de las mujeres: «Al final hasta la más fea sale a la calle con paso de Miss Universo [...] Y no mira a nadie sintiéndose como un travesti en el Vaticano» (20). Pero también la loca-peluquera utiliza el artificio de sus manos para cobrar su trabajo con el cuerpo de un joven que se va al servicio militar. El final de la crónica revela asimismo que el quehacer y el oficio de la Loca es una forma más de enclaustrarla y controlarla, «Aun así, las manos tarántula de las locas tejen la cara pública de la estructura que las reprime, traicionando el gesto puritano con el rictus burlesco que parpadea nostálgico en el caleidoscopio de los espejos» (20). En este sentido, Sierra (2002) sostiene que el cuerpo es un espacio travestido de maquillajes y aderezos del mismo modo en que la ciudad describe una geografía de encubrimiento del deseo. «Y de manera adicional, la escritura de 
la crónica es el texto que metaforiza esa relación. Los entretejidos del pelo son un espejo de las tramas que se diseñan en el espacio neoliberal de los noventa» (95).

\section{Loco afán. Crónicas de sidario}

En 1996, Pedro Lemebel publica su segundo libro de crónicas, Loco afán. Crónicas de sidario. En él, deambulamos por la «ciudad sidada» narrada a partir de las historias de los habitantes, por decirlo de algún modo, de esa ciudad. Es decir, el topos se construye con los fragmentos que se encuentran dispersos en los márgenes de la otra ciudad, la real. El cronista se vuelve testigo-protagonista de la marginalidad, el dolor e incluso la muerte ocasionada por la enfermedad. Desde la portada del libro en el que se retrata Las dos Fridas (recreación trasvestida e invertida que habían hecho en 1989 Las Yeguas del cuadro de Frida Kahlo), Lemebel enlaza e inscribe su cuerpo con su letra. El performance no dejó de existir, se desliza en la textualidad de las crónicas que devienen, casi por añadidura, en performáticas. Así, como sostiene Urtasun,

Las crónicas de Loco afán reescriben el cuerpo sidoso, no para construir explícitamente los trazos que determinan el cuerpo normalizado y normativizado sino más bien para reinscribir las marcas de una cartografía corporal posible, para destacar su recorrido, hacerlo visible. Las crónicas, al postular el cuerpo como materia escribible, es decir mostrar su condición textual, hacen visible el contrato de una mirada y una escritura, entre un punto de vista y un mapa particular del cuerpo. (208)

Es en este sentido que «La muerte de Madonna» constituye una crónica

que se relaciona directamente con la acción artística que habían creado Las Yeguas del Apocalipsis, Lo que el SIDA se llevó, organizada en el Museo 
CATEDRAL TOMADA: Revista literaria latinoamericana / Journal of Latin American Literary Criticism

Performance: travestismos y política en las crónicas de Pedro Lemebel

Nacional de Bellas Artes luego del retorno a la democracia, porque la protagonista de esta historia había sido una de las modelos de las fotografías expuestas en la performance. «La exposición no tenía censura previa, por lo que la Madonna de San Camilo pasó colada en el video «Casa Particular», que Gloria Camiruaga había realizado con las "Yeguas del Apocalipsis" en la calle travesti» (Lemebel 36). La crónica empieza narrando la vida de la Madonna, quien

antes tenía otro nombre. Pero cuando la vio por la tele se enamoró de la gringa, casi se volvió loca imitándola, copiando sus gestos, su risa, su forma de moverse. La Madonna tenía cara de mapuche, era de Temuco, por eso nosotros la molestábamos, le decíamos Madonna Peñi, Madonna Curilagüe, Madonna Pitrufquén. (Lemebel 32).

En la misma textualidad de la crónica, Lemebel incorpora la anécdota que ocurre dentro la muestra artística que incluía muchos géneros, entre ellos performances, videos, instalaciones. A la vista de alumnos y profesores que la visitaban en uno de los momentos fílmicos del video que se transmitía, el elástico que sujetaba el pene de la Madonna se suelta y desborda la pantalla. «Todo es fiesta cuando la sala se repleta de otros escolares que visitaban el museo, tocándose, jugando a los agarrones, viendo una y otra vez la rápida metamorfosis, la repetición incansable del video reiterado en la cinta» (Lemebel 37). Más allá de la anécdota, en el interior de la crónica se deslizan diferentes repeticiones de la misma imagen en diferentes situaciones y contextos, una travesti que se traviste de Madonna, una multiplicidad de figuras de Madonna en la habitación de la loca, una fotografía en una performance durante la dictadura y por último, la misma fotografía en un video, que es expuesto en una muestra, ahora en la democracia, en la que se exhibe la «masculinidad» de La Madonna. No debemos olvidar que «la cuestión de la fotografía se convierte, en ese momento, en referencia central para el debate artístico en Chile. La fotografía cumple aquí tanto el papel de "guardián de la memoria" como de vehículo del experimentalismo vanguardista 
de las poses hiperestilizadas, simulaciones y juegos de máscaras» (Avelar, 137). Es decir, Lemebel avanza en la narración por fragmentos que se van hilvanando y que van mutando en otra cosa a medida que el contexto cambia. Lo único que queda fijo, inmóvil como la fotografía, es el sida.

En «El último beso de la Loba de Mar (Crespones de seda en mi despedida... por favor)», Lemebel es testigo de la muerte de La Madonna, quien había sido infectada por el virus del sida. Pero el relato de la enfermedad y la muerte es pronunciado en la crónica, al igual que en muchas otras, a través de la mueca y la risa. El sufrimiento es socavado por la última acción que realizan sus compañeras para simular el cuerpo abyecto producto de la enfermedad y modelarlo en un cuerpo que pareciese viviente y estético:

Casi una hora le tuvo los pómulos apretados con esa tenaza. Hasta que la carne volvió a tomar su fúnebre rigidez. Sólo entonces la soltó, y todas pudimos ver el maravilloso resultado de esa artesanía necrófila. Nos quedamos con el corazón en la mano, todas emocionadas mirando a la Loba con su trompita chupona tirándonos un beso. Habrá que taparle los moretones, dijo alguna sacando su polvera Angel Face. ¿Y para qué? Si el rosa pálido combina bien con el lila cerezo. (Lemebel 40)

Como sostiene Butler en relación a la teoría queer, el sida aparece teatralizado (hiperbolizado) para exhibir de manera hiperbólica la muerte y dolor y «para aplastar la resistencia epistémica al sida y a la gráfica del sufrimiento» (328).

Para finalizar, profundizaré la relación entre cuerpo-performance-crónica en dos textos, que antes de «travestirse» en crónicas en el conjunto de un libro, constituyeron intervenciones políticas y sociales. El primero es «Manifiesto (hablo por mi diferencia)» que Lemebel proclamó en un acto político de izquierda en septiembre de 1986, en Santiago de Chile. Es un texto que conforma una 
CATEDRAL TOMADA: Revista literaria latinoamericana / Journal of Latin American Literary Criticism

Performance: travestismos y política en las crónicas de Pedro Lemebel

declamación con tinte teatral, ya que apela al uso de la voz y el cuerpo. La declamación, que a comienzos del siglo había servido a la formulación de una voz nacional, en Lemebel, dice Garbatzky, se invierte y convierte en «un soporte donde problematizar aquellas identidades que el espectro declamador había negado, en especial las emergencias ligadas a la diversidad sexual» (160). En el Manifiesto se hace visible la homosexualidad en el contexto de la democracia chilena, pero también hay alusión a los desaparecidos, a la clase social proletaria, al sida. A continuación citaré uno de los fragmentos, según nuestra opinión, más significativo:

Aunque después me odie/Por corromper su moral revolucionaria/ ¿Tiene miedo que se homosexualice la vida?/Y no hablo de meterlo y sacarlo/Y sacarlo y meterlo solamente/Hablo de ternura compañero/Usted no sabe/Cómo cuesta encontrar el amor/En estas condiciones/Usted no sabe/Qué es cargar con esta lepra/La gente guarda las distancias/La gente comprende y dice:/Es marica pero escribe bien/Es marica pero es buen amigo. (Lemebel 86)

En la declamación-intervención, aparece tanto la denuncia política a la izquierda que no lo aceptó por ser homosexual, como al capitalismo por convertir en mercancía la diferencia. Pero sobre todo es un texto político orientado a las generaciones futuras: «Hay tantos niños que van a nacer/Con una alita rota/Y yo quiero que vuelen compañero/Que su revolución/Les dé un pedazo de cielo rojo/Para que puedan volar» (Lemebel 88). Este manifiesto constituye el paradigma en la escritura de Pedro Lemebel del vínculo entre poesía, política y sexualidad, traspasado por el cuerpo y la letra. Y es también el hilo que enlaza, el continuum, la denuncia y el rechazo político a la dictadura como a la posdictadura chilena.

El segundo texto lleva como título «Loco afán» y también fue leído como declamación en el encuentro que tuvo Felix Guattari con alumnos de la 
Universidad Arcis en Chile, en 1991. En esta crónica pronunciada, creemos que también confluyen todos los vínculos entre la performance y la crónica en Pedro Lemebel. En primer lugar, el escritor-performance escribe -habla - acerca del cruce de fronteras entre géneros, pero también del más allá de los géneros sexuales (el travesti, el devenir hombre y el devenir mujer). Citaré dos fragmentos significativos:

Vadeando los géneros binarios, escurriéndose de la postal sepia de la familia y sobre todo escamoteando la vigilancia del discurso; más bien aprovechando sus intervalos y silencios; entremedio y a medias, reciclando una oralidad del detritus como alquimia excretora que demarca en el goce esfinteral su crónica rosa. Me atengo a la perturbación de este aroma para comparecer con mi diferencia. (Lemebel 116)

Tal vez lo único que decir como pretensión escritural desde un cuerpo políticamente no inaugurado en nuestro continente sea el balbuceo de signos y cicatrices comunes (Lemebel 120).

Lemebel enuncia y declama desde ese lugar que se presenta como más allá de los géneros porque es desde allí donde puede escamotearse de la vigilancia estatal y discursiva. Con silencios, intervalos, balbuceos, (el más acá del lenguaje derridiano), emerge lo político que en este contexto se lee más como resistencia que como trasgresión. Sería en este sentido que Lemebel se apropia del concepto gay, utilizado por la sociedad para patologizar y degradar a los homosexuales, para resignificarlo y usarlo como una categoría de resistencia:

Lo gay se suma al poder, no lo confronta, no lo transgrede. Propone la categoría homosexual como regresión al género. Lo gay acuña su emancipación a la sombra del «capitalismo victorioso» [...] Quizás América Latina travestida de traspasos -reconquistas y parches culturales - 
CATEDRAL TomAdA: Revista literaria latinoamericana / Journal of Latin American Literary Criticism

Performance: travestismos y política en las crónicas de Pedro Lemebel

que por superposición de injertos sepulta la luna morena de su identidadaflore en un mariconaje guerrero que se enmascara en la cosmética tribal de su periferia. Una militancia corpórea que enfatiza desde el borde de la voz un discurso propio y fragmentado, cuyo nivel más desprotegido por su falta de retórica, orfandad política sea el travestismo homosexual que se acumula lumpen en los pliegues más oscuros de las capitales latinoamericanas. (subrayado mío, Lemebel 119)

Las denuncias al Estado - y a la sociedad- por las torturas y muertes a los homosexuales y al mercado que - tras la matriz estadounidense - borra las prácticas sociales, culturales y artísticas locales, emitidas desde un cuerpo devenido políticamente incorrecto hacen posible, al mismo tiempo, la aparición y visibilidad de ese cuerpo que retoma las voces de los demás cuerpos marginados. En la cita, se cifra la acción política, artística y social de Pedro Lemebel tanto en lo que refiere a su militancia corpórea en el colectivo artístico Las Yeguas del Apocalipsis como a la escritura de una voz propia y fragmentada que se manifiesta en las crónicas literarias trabajadas.

\section{Cronicar desde el cuerpo}

La puesta en práctica procesual de la performance como forma de intervenir en el mundo que permite a los sujetos que la realizan transformarse y transformar sus vínculos con los otros parece no haber dejado nunca de cesar en Pedro Lemebel. Esta cuestión relevante es, sin duda, insoslayable cuando abordamos también su literatura. No existen dos momentos en la vida intelectual del chileno, no podemos escindir al performance del escritor. El primero aprovisiona al otro que se desenvuelve en las textualidades poéticas y barrocas. Lemebel es más que un cronista del margen, es el cronista del cuerpo del presente 
desde el cual las nociones esencialistas de identidad, género, nación que habían fundado y consolidado los relatos totalizadores y homogéneos de la modernidad latinoamericana deben redefinirse. La diferencia y la teatralidad que definen los cuerpos de las múltiples Locas, que el cronista visibiliza, y del mismo Lemebel componen una voz performativa que interpela y sacude las normas heterónomas. Tretas de una escritura vivencial y corporal siempre dispuesta a «traicionar el empadronamiento oficial que pestañea al compás de los semáforos dirigiendo el control ciudad-ano» (Lemebel Loco 80), las crónicas literarias constituyen un acto de performance desde varios sentidos: el intersticio de géneros, una intervención de denuncia y protesta, la teatralidad como herramienta para hacer ver el cuerpo homosexual desde el margen y una escritura basada en una textualidad corporal.

La literatura lemebeliana deviene performance y archivo, guardiana de una memoria erótica presente silenciada en la ciudad letrada y en la ciudad real no con violencia sino con las transacciones impuestas desde el Mercado. La cartografía que propone Lemebel desde su cronicar corporal desafía con insistencia a esa democracia neoliberal donde vale todo significa la exclusión de los cuerpos marcados por la globalización y la desintegración de lo nacional en lo trasnacional. Para concluir, suspendemos nuestra escritura para dejar que siga resonando la voz sarcástica e imponente de Lemebel: «Para qué deprimirse con la difícil unidad latinoamericana y el triunfo del capitalismo; si aún nos queda humor, desacato y cuerda para carretear este fin de siglo.» (Loco 137) 
CATEDRAL TOMADA: Revista literaria latinoamericana / Journal of Latin American Literary Criticism

Performance: travestismos y política en las crónicas de Pedro Lemebel

\section{Bibliografía}

Avelar, Idelber. Alegorias de la derrota: la ficción postdictatorial y el trabajo del duelo. Santiago de Chile: Editorial Cuarto Propio, 2000. http://www.tecc.arte.unicen.edu.ar/download/secretinvest/becas/lusnich/alegorias.pdf

Blanco, Fernando y Gelpí, Juan. «El desliz que desafía otros recorridos. Entrevista con Pedro Lemebel», en Nómada: creación, teoría, critica 2, Puerto Rico, 1997.

Butler, Judith. «Introducción», «Los cuerpos que importan», «Acerca del término queer», en Cuerpos que importan. Sobre los límites materiales y discursivos del sexo. Buenos Aires: Paidós, 2002.

Garbatzy, Irina. Los ochenta recienvivos. Poesía y performance en el Río de la Plata. Rosario: Beatriz Viterbo Editora, 2013.

Gareca, Maricruz. «Pedro Lemebel y la crónica urbana. Nuevas voces y miradas». Revista del CCC. Septiembre / Diciembre 2012, N $\mathrm{N}^{\circ} 16$. http://www.centrocultural.coop/revista/articulo/350/. 7 de junio2015.

Laddaga, Reynaldo. Espectáculos de realidad. Rosario: Beatriz Viterbo, 2007.

Lemebel, Pedro (1995). La esquina es mi corazón. Chile: Seix Barral, 2004.

(1996). Loco afán. Crónicas de sidario. Barcelona: Editorial Anagrama, 2000.

Link, Daniel. «Cuerpo y memoria en América Latina: El archivo de "la loca" como sujeto colonial», en A contracorriente. Una revista de historia social y literatura de América Latina, North Carolina State University, Department of Foreign Languages and Literatures, Vol. 12, $\mathrm{N}^{\circ}$. 1, Fall 2014. 264-277

Longoni, Ana. «Conceptualismo», en Territorio Teatral IUNA, Buenos Aires, 2007, $\mathrm{N}^{\circ}$ 1. www.territorioteatral.org.ar/html.2/dossier/01.html. 10 de enero 2015. 
Masiello, Francine. El arte de la transición. Buenos Aires: Grupo Editorial Norma, 2001.

Moreno, María. «Perlongher en primera» en El fin del sexo y otras mentiras. Editorial Sudamericana, Buenos Aires, 2002.

Neustadt, Robert. «El grupo CADA. Acciones de arte en el Chile dictatorial» en $\begin{array}{lllll}\text { Revista conjunto, } & \text { Enero-Marzo 2003. } & \mathrm{N}^{\circ} & 127 .\end{array}$ ttp://www.casa.cult.cu/publicaciones/revistaconjunto/127/robert.htm. 11 de febrero 2015.

Pastén, Agustín. «Paseo crítico por una crónica testimonial: de La esquina es mi corazón a Adiós mi mariquita linda de Pedro Lemebel» en A contra corriente, Vol. 4, $\mathrm{N}^{\circ}$ 2, 2007 www.nesu.edu/project/acontracorriente. 11 de abril 2015.

Poblete, Juan. «Crónica y ciudadanía: en tiempos de globalización neoliberal: la escritura callejera» en Tras las huellas de una escritura en tránsito. La crónica contemporánea en América Latina. Ed. Graciela Falbo, Buenos Aires: Ediciones Al margen, 2007.

Richard, Nelly. Fracturas de la memoria: Arte y pensamiento crítico. Buenos Aires: Siglo XXI Editores, 2007.

«Desplazamientos de soportes y borradura de las fronteras entre los géneros.» en Márgenes e Instituciones. Arte en Chile desde 197. Santiago de Chile: Ediciones Metales Pesado, 2007. 89-98.

Robino, Carolina. «Las Yeguas del Apocalipsis. Las últimas locas del fin del mundo», en Revista Hoy, Araucaria, 1977-1998, 21 v., N. 736 (ago. 26sept. 1, 1991), 42-47.

Sabo, María José «Lugares teóricos de construcción de valor: la crónica y el testimonio», ponencia presentada en el VII Encuentro Interdisciplinario de Ciencia sociales y humanas, Facultad de Filosofía y Humanidades, Córdoba, Argentina. Septiembre 2011. Disponible online en publicaciones.ffyh.unc.edu.ar/index.php/7encuentro/article/.../515 
CATEDRAL Tomada: Revista literaria latinoamericana / Journal of Latin American Literary Criticism

Performance: travestismos y política en las crónicas de Pedro Lemebel

«La crónica como género en construcción y la construcción del gender. Abordaje desde la performance.» Ponencia presentada en Jornadas de Estudios de la Performance $\mathrm{N}^{\circ} 1$. Organizadas y coordinadas por el equipo de investigación "Subjetividades Contemporáneas" (CIFFyH- Museo de Antropología, Universidad Nacional de Córdoba, 2012. 1-8.

Sarduy, Severo. La simulación. Venezuela: Monte de Ávila Editores, 1982. «El barroco y el neobarroco» en Obras completas. México: F.E.C, 1999.

Sierra, Marta. «Los espacios de la crónica en La esquina es mi corazón de Pedro Lemebel» en Tras las huellas de una escritura en tránsito. La crónica contemporánea en América Latina. Ed. Graciela Falbo, Ediciones Al margen, Buenos Aires, 2007.

Taylor, Diana. «Introducción» en Taylor, Diana y Fuentes, Marcela (comps.) Estudios avanzados de performance. México: FCE, 2011.

Urtasun, Marta. « Locas que importan: crónicas de sidario de Pedro Lemebel» en Anclajes, $\quad$ diciembre 2006. 201-213. http://ojs.fchst.unlpam.edu.ar/ojs/index.php/anclajes/article/view/273/252

Zeiger, Claudio. «Yeguas del Apocalipsis», Página 12, 9 de septiembre del 2000: Radar Libros. http://www.pagina12.com.ar/2000/suple/libros/00-09/00-0917/nota1.htm\#111 6 de julio 2015. 